Article

\title{
A New Regulatory Approach for PV-Based Self-Supply, Validated by a Techno-Economic Assessment: A Case Study for Slovenia
}

\author{
Luka Martin Tomažič ${ }^{1}$, Niko Lukač ${ }^{2, *(1)}$ and Gorazd Štumberger ${ }^{2}(\mathbb{D}$ \\ 1 Alma Mater Europaea_ECM, Slovenska Ulica 17, 2000 Maribor, Slovenia; luka.tomazic@almamater.si \\ 2 Faculty of Electrical Engineering and Computer Science, University of Maribor, \\ Koroška Cesta 46, 2000 Maribor, Slovenia; gorazd.stumberger@um.si \\ * Correspondence: niko.lukac@um.si; Tel.: +386-2-220-7435
}

check for

updates

Citation: Tomažič, L.M.; Lukač, N.; Štumberger, G. A New Regulatory Approach for PV-Based Self-Supply, Validated by a Techno-Economic

Assessment: A Case Study for

Slovenia. Sustainability 2021, 13, 1290 https://doi.org/10.3390/su13031290

Received: 2 December 2020

Accepted: 21 January 2021

Published: 26 January 2021

Publisher's Note: MDPI stays neutral with regard to jurisdictional claims in published maps and institutional affiliations.

Copyright: (c) 2021 by the authors. Licensee MDPI, Basel, Switzerland. This article is an open access article distributed under the terms and conditions of the Creative Commons Attribution (CC BY) license (https:// creativecommons.org/licenses/by/ $4.0 /)$.

\begin{abstract}
When it comes to the proliferation of photovoltaic (PV) systems, technological solutions have to go hand in hand with optimized policy approaches and regulatory frameworks. This paper proposes a new application of state-of-the-art PV potential estimation method based on Light Detection And Ranging (LiDAR) data targeted toward individual household self-supply. The performance of the proposed general approach is demonstrated in the case of Slovenian PV based self-supply (yearly net self-sufficient energy supply) scheme and related policy. The results obtained by PV potential assessment method show drawbacks of the current policy solution in Slovenia, which limits the installed peak power of the PV systems to $80 \%$ of the rated power supply. The paper proposes to change the policy in a way that increases the yearly energy production of the PV system and assures proper voltage profiles in the electricity network. The paper is novel in terms of considering PV potential over LiDAR data by also considering self-sustainability, in using such techno-economic analysis to validate the merits and demerits of a policy approach and is the first such case study used in the context of Slovenian self-supply policy. The proposed PV potential estimation method is generally applicable for any location and can be easily adjusted to the local regulatory framework.
\end{abstract}

Keywords: PV systems; electricity self-supply; energy law and policy; techno-economic potential

\section{Introduction}

The proliferation of Photovoltaic (PV) systems is driven, besides the technological development, by policies at the level of the European Union (EU) and at the level of individual countries in the EU. In the past few years, ambitious goals were set based on the European Commission's "Winter Package 2016" for the EU to achieve the transition to a clean energy economy and to reform and improve the EU electricity market [1-3]. Individual member states enact their own regulatory frameworks in an individual fashion, while still complying with EU-wide policies. The implementation of the Winter Package in various European countries has been completed EU-wide and important amendments of existing primary and secondary legislation have already taken place, especially with regard to the so-called self-supply using PV systems [4], which is actually a yearly net self-sufficient energy supply, where yearly energy production matches yearly consumption. On one hand, these amendments aim to remove regulatory barriers to the proliferation of PV systems on multi-dwelling buildings, and on the other hand they alter the approach regarding rules for connecting the PV systems owned by households and small businesses to the electricity distribution network. With this, Slovenia is aiming to reach the ambitious targets regarding sustainable energy use, set by the EU. With this, EU countries, including Slovenia, are aiming to reach the ambitious targets regarding sustainable energy use, set by the EU. This of course requires considerations of not only the environmental aspects of energy usage and production, but also economic regulation, while still ensuring an acceptable level of network stability and power supply reliability. 
In the past few years various new methods have been developed for estimating solar and photovoltaic over 3D buildings surfaces, where the most prominent technology to represent the buildings in a large-scale fashion is airborne LiDAR (Light Detection And Ranging). Airborne LiDAR works by emitting a laser pulse to a target surface from an aircraft, which is then reflected and absorbed back at the aircraft sensor. Based on the time duration of the laser pulse, the distance to the surface can be estimated and consequently a 3D georeferenced point can be calculated. The result of LiDAR scan is a large unstructured point cloud data consisting of billions of 3D points representing the scanned surface. This provided new opportunities for more accurate solar and PV potential (i.e., a per-annum energy generation yield) estimation, where multiple methods have been developed in the past few years. They considered different discrete topological structures over LiDAR data to solve the given problem (e.g., 2.5D grid structures and digital surface models, triangulated irregular networks, or extracted 3D models) [5]. Tooke et al. [6] and Brito et al. [7] considered 2.5D grid topology in order to efficiently estimate shadowing from the surroundings when estimating solar potential. Similarly, Lukač et al. [8] used the same topological structure, while also representing shadowing from wider surroundings, shadowing from vegetation, and consideration of nonlinear efficiency characteristics for estimating PV potential over LiDAR data. Jakubiec et al. [9] considered Triangulated Irregular Network (TIN) topology, in order to estimate PV potential over 3D buildings based on PV nonlinear efficiency model considering the ambient temperature. Similarly, Lingfors et al. [10] considered TIN in various resolutions in order to estimate shading influence on solar potential more efficiently. Assouline et al. [11,12] used machine learning approaches over reconstructed 3D buildings data to estimate the solar potential. While the aforementioned state-of-the-art methods focus on techno-economic PV potential over 3D buildings based on LiDAR, they do not consider self-sustainability or self-supply schemes. Recently, Bizjak et al. [13] used solar potential calculation within thermal load estimation over 3D extracted models from LiDAR data.

On the other hand, PV-systems in connection with self-sustainability is a current research topic as well [14]. Nikolovski et al. [15] has shown analysis in peak power saving with a focus on forecasting peaks, however regulatory aspects were not taken into account. Prenc et al. [16] took into account consumption and production fluctuation analysis in order to determine the optimal PV system placement in a distribution network. Prata and Carvalho [17] have performed a policy analysis regarding self-supply, while taking into account both market evolution and network sustainability. Davies and Carley [18] have performed an analysis of net-metering for PV systems, while taking into account legislative aspects, with techno-economic validation on a regional level, however their accuracy is limited when taking into account individual 3D buildings.

In this paper a quantitative analysis is performed by using a state-of-the-art simulation method for PV techno-economical potential assessment, by considering 3D buildings based on LiDAR remote sensing data, as well as long-term meteorological measurements. The simulation-driven methodology considers the influence of direct and diffuse solar irradiances based on surface topography (i.e., slope and aspect), as well as shadowing from the surroundings. The PV-based electrical energy production is estimated by considering nonlinear efficiency characteristics of a PV system, while the production is equal to the household total power supply, in order to reach self-supply. The presented generally applicable methodology was demonstrated on an urban city of Maribor and rural area of Pekre, Slovenia, while also considering the regulatory aspects of Slovenia self-supply policies, and proposing an improved self-supply scheme. More specifically, a critical policy analysis is performed by using the results of the techno-economic assessment and applying it to the Slovenian self-supply policy framework. Based on the results it is proposed which potential regulatory amendments might be useful to achieve the optimal exploitation of PV systems in terms of the Slovenian self-supply policy framework.

This paper makes the following contributions in regard to the state-of-the-art: 
- This is the first attempt by using techno-economic potential estimation based on LiDAR data that is targeted toward self-supply. The predicted PV energy production is hence limited by the total power supply of the considered households, in order to reach self-supply.

- $\quad$ The proposed paper provides simple yet effective improvements to the self-supply policy of Slovenia and validates the proposed changes with quantitative state-of-theart techno-economic assessment. The proposed PV potential estimation method is generally applicable and can be easily adjusted to the local regulatory framework in other locations.

- It is the first analysis performed of the self-supply policy framework focusing on the legal and policy framework, where Slovenia is used as a case study. Thus, the paper has interdisciplinary merit and is a novelty both regarding policy sciences as well as the field of energy law and regulation in Slovenia.

The paper is structured into five sections. The second section discusses the generally applicable methodology which is applied in the third section, where the results for the case study of Slovenia are presented. The results section is split into three subsections, the first one pertaining to the general results of the techno-economic analysis, the second one presenting the regulatory framework in the case of Slovenia and the third one performing a further analysis taking into account the current and the proposed alternative policy approach. In the fourth section a discussion is performed, which aims to illuminate the regulatory and policy frameworks in light of the results. In the final section, conclusions are drawn.

The main issue explored by this paper is thus the manner in which the existing policy and regulatory framework for self-supply can be optimized using a techno-economic analysis based on the state-of-the-art photovoltaic potential estimation by applying the results of such analysis to propose a more efficient regulatory approach. We have researched the existing regulatory framework in Slovenia, performed the techno-economic analysis based on PV potential estimation and proposed a novel, more efficient policy approach. Necessary changes in laws and regulations are proposed. The paper itself is a case study focused on the framework of the Republic of Slovenia, but the proposed PV potential estimation method has a potential for broader application and is adjustable to different national and local regulatory frameworks.

\section{Materials and Methods}

In this paper the state-of-the-art photovoltaic potential estimation based on [8] is considered, where LiDAR point cloud data is used, in order to obtain 3D geometric details about the surrounding terrain and buildings' rooftops. LiDAR is an active remote sensing technology, where a laser pulse is emitted from an aircraft or terrestrial vehicle, in order to scan the surface. A 3D georeferenced point is estimated based on the elapsed time since the laser pulse is reflected from the surface back to the receiver next to the laser scanner. Ultimately, a 3D point cloud is estimated from the scanned surfaces consisting of millions of points, which have to be adequately classified into different entities (i.e., terrain, vegetation and buildings). This paper does not deal with LiDAR data classification and preprocessing, for more details see [19]. The overall approach for the estimation of the considered method for techno-economic photovoltaic potential assessment can be seen in Figure 1.

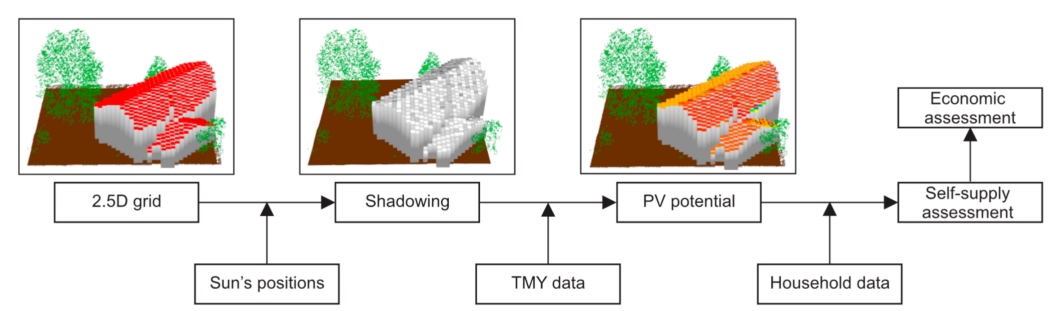

Figure 1. Workflow of the proposed method for self-supply assessment. 
At first the point cloud data of the terrain and buildings is inserted into 2.5D topological grid $G$, where each point $p_{i}$ belongs to its closest cell $c_{j} \in G$. The height of the cell is defined as the maximum height of the $m$ points located within the cell, i.e., $c_{j} . z=\max \left(p_{i} . z, \ldots p_{m} . z\right)$, while the slope $\beta_{j}$ and aspect $\gamma_{j}$ of each $c_{j}$ are estimated by estimating the normal vectors (see [8]). Once the 2.5D grid is constructed, the technical photovoltaic potential for each cell $P_{j}(1)$ belonging to a rooftop surface, can be estimated as [8]:

$$
P_{j}=\sum_{t=1}^{8760} P^{S Y S}\left(I_{b}(t) \frac{\cos \theta_{j}}{\cos \theta_{z}}\left(1-S_{j}(t)\right)+\operatorname{Perez}\left(I_{d}(t), \beta_{j}, \theta_{j}, \theta_{z}\right)\right)[\mathrm{kWh}]
$$

where an hourly time-step is used (i.e., $t=1$ for $1 \mathrm{~h}$ ). The $P^{S Y S}(2)$ transforms the input solar irradiance into power by considering the non-linear efficiency characteristics of a given PV system (i.e., based on efficiency of a given micro-inverter and module), defined as [8]:

$$
\begin{gathered}
P^{S Y S}\left(I_{C_{i}}(t)\right)=\eta_{j}^{i n v} \eta_{j}^{X}\left(I_{j}(t)\right) I_{j}(t) A_{j}[\mathrm{~W}] \\
\eta_{j}^{X}\left(I_{C_{i}}(t)\right)=x_{1}\left(x_{2}\left(\frac{I_{j}(t)}{1000}\right)+\left(\frac{I_{j}(t)}{1000}\right)^{x_{3}}\right)\left(2+x_{4}+x_{5}\right) \\
\eta_{j}^{\text {inv }}\left(\eta_{j}^{X}\left(I_{C_{i}}(t)\right)\right)=-0.287 e^{-0.0366 \eta_{j}^{X}\left(I_{C_{i}}(t)\right)}-0.655 e^{-0.1575 \eta_{j}^{X}\left(I_{C_{i}}(t)\right)}+0.942
\end{gathered}
$$

where $\eta_{j}^{X}(3)$ and $\eta_{C_{i}}^{\text {inv }}(4)$ are the efficiency characteristics of a given PV module (for coefficients $x_{1}$ to $x_{2}$ see [8]), and micro inverter, respectively. $A_{j}\left[\mathrm{~m}^{2}\right]$ defines the area of the PV module for the $\mathrm{j}$-th cell. $I_{j}(t)$ is the total irradiance the $\mathrm{j}$-th cell receives, which is further broken down into direct and diffuse per-surface irradiances. The $I_{b}(t)$ and $I_{d}(t)$ denote instantaneous horizontal direct and diffuse irradiance for the given time instant, respectively. Both are based on estimated Typical Meteorological Year (TMY) [20] over long-term measurements from a pyranometer at the nearby meteorological station. The horizontal direct irradiance $I_{b}$ is adequately adjusted to an arbitrary surface (in our case the surface of cell $c_{j}$ ) by considering the angle of incidence $\theta_{j}(5)$ and the solar zenith angle $\theta_{z}(6)$, defined as [21]:

$$
\begin{gathered}
\cos (\theta)=\sin (\delta(n)) \sin (\varphi) \cos (\beta)-\sin (\delta(n)) \cos (\varphi) \cos (\beta) \\
-\cos (\delta(n)) \cos (\varphi) \cos (\beta) \cos (\gamma) \\
+\cos (\delta(n)) \cos (\varphi) \sin (\beta) \cos (\gamma) \cos (\Omega(H)) \\
+\cos (\delta(n)) \cos (\varphi) \sin (\gamma) \sin (\Omega(H)) \\
\cos (\theta \mathrm{z})=\cos (\delta(\mathrm{n})) \sin (\varphi \mathrm{i}) \cos (\Omega(\mathrm{H}))+\sin (\varphi \mathrm{i}) \sin (\delta(\mathrm{n}))
\end{gathered}
$$

where $\varphi$ is the geographical latitude, $\Omega(\mathrm{H})=0,261799(\mathrm{H}-12)$ is the hour angle for given hour $H$, and $\delta(n)$ is the solar declination (7) defined by Spencer [22] as:

$$
\begin{aligned}
& \delta(n)=(180 / \pi)(0.006918-0.399912 \cos (B)+0.070257 \sin (B) \\
& -0.006758 \cos (2 \mathrm{~B})+0.000907 \sin (2 \mathrm{~B})-0.002697 \cos (3 \mathrm{~B}) \\
& +0.00148 \sin (3 \mathrm{~B}))
\end{aligned}
$$

where $n$ is the day in year, and $B=(n-1) /(360 / 365)$. In this paper, the anisotropic diffuse irradiance model by Perez is considered (see [23]), in order to estimate more accurately the per-cell diffuse irradiance. The estimated per-cell direct irradiance is also decreased by the 
shadowing coefficient $S_{j}(t)(8)$ for the given cell $c_{i}$ in case it is shadowed by another cell $c_{k}$. The shadowing coefficient is hence estimated as [8]:

$$
S_{j}(t)=\left\{\begin{array}{cc}
1 c_{j} . z<c_{k} . z-d_{2}\left(c_{j}, c_{k}\right) \frac{\mathbf{s}_{z}(t)}{\sqrt{\mathbf{s}_{x}^{2}(t)+\mathbf{s}_{y}^{2}(t)}} \\
0 & \text { otherwise }
\end{array},\right.
$$

where s denotes the Sun's light directional vector for time instant $t$, and depends on the position of the Sun for the given time and location. In order to estimate the position of the Sun more accurately, the SOLPOS algorithm is considered [24]. Once the photovoltaic potential is known, the economic potential can be estimated by considering the wellestablished Net Present Value (NPV) (9) economic metric. Hence, the per-cell NPV can be estimated as:

$$
N P V_{j}=\sum_{y=1}^{N} \frac{F P_{j} \alpha(y)}{(1+r)^{y}}-I N V
$$

where the numerator represents the return of investment for the given year $y$ consisting of feed-in-tarrif $F[\epsilon]$ coefficient for $1 \mathrm{kWh}$ of annually generated electrical energy, and $\alpha(y)$ is the degradation coefficient for the given PV system configuration for the given year. Parameter $r$ is the discount rate for the given region, while INV $[€]$ represents the initial investment cost for the considered PV system.

\section{Results}

This section is split into four subsections in order to ensure a more clear and transparent presentation of results and the discussion thereof. First, the results of the photovoltaic potential assessment based on LiDAR scan dataset of Maribor's city centre and rural area of Pekre, Slovenia presented. Then, the relevant results of the analysis of the Slovenian regulatory framework pertaining to self-supply is performed. In the third section, the existing regulation is taken into account to propose an improvement in the policy approach, which aims to achieve optimum production. Finally, yet importantly, a discussion is performed, putting the obtained results into a broader context and making specific policy recommendations for the case study of Slovenia.

\subsection{Photovoltaic Potential Assessment}

The proposed method was tested on airborne LiDAR scan dataset of Maribor's city centre, Slovenia $\left(46.5547^{\circ} \mathrm{N}, 15.6459^{\circ} \mathrm{E}\right)$ and rural area of Pekre, Slovenia $\left(46.5462^{\circ} \mathrm{N}\right.$, $\left.15.5951^{\circ} \mathrm{E}\right)$. At first, the given data was classified into buildings, terrain and vegetation. Afterwards a $2.5 \mathrm{D}$ grid was constructed, with $1 \mathrm{~m}^{2}$ per-cell resolution, over point cloud data in order to gain topological features, as can be seen in Figure 2. The data was segmented based on buildings outlines (see Figure 2a,c), obtained from Slovenian mapping authority [25]. This is a vital preprocessing step, since the number of households is publicly known for each building. Figure $2 b$,d shows the buildings coloured based on the number of households.

Once the preprocessing was complete, the PV potential, with 1-h time-step, was estimated for each grid cell based on the aforementioned method. Hence, each grid cell represents a $1 \mathrm{~m}^{2}$ hypothetical PV system. The input direct and diffuse irradiances were estimated by constructing TMY over long-term measurements from nearby airport, provided by the Slovenian meteorological agency [26]. The resulting PV potential (i.e., cumulative annual energy production in $\mathrm{kWh}$ ) for the Monocrystalline Silicon (M-Si) type of module with micro inverter is shown in Figure 3. In this paper, the efficiencies of the M-Si module and micro inverter are based on [8], and were estimated by linear regression over PV system's measurements. 


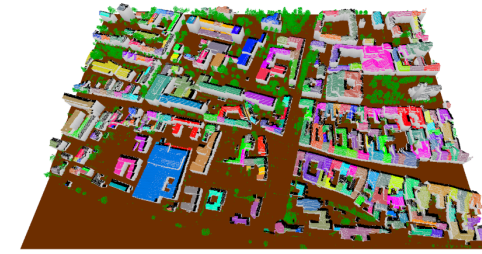

(a)

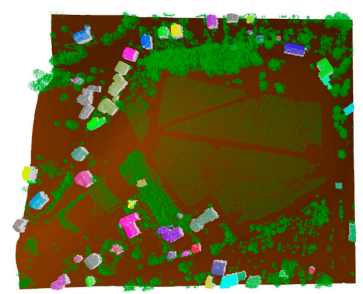

(c)

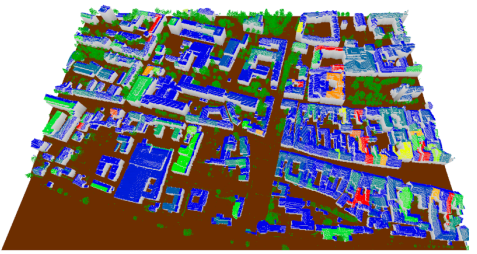

(b)

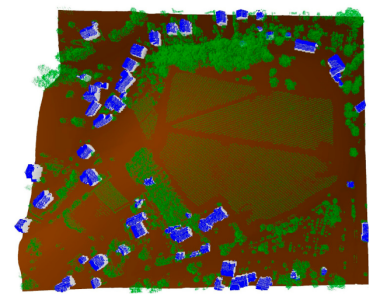

(d)

Figure 2. LiDAR 2.5D grid coloring based on (a,c) building's outlines, and $(\mathbf{b}, \mathbf{d})$ number of households, where the first row represents urban area of Maribor, and the second column the rural area of Pekre, Slovenia. (coloring: blue $=1$ house-hold, green $=[2,5]$ households, yellow $=[5,10]$ households, orange $=[10,20]$ households, and red $=$ more than 20 households.

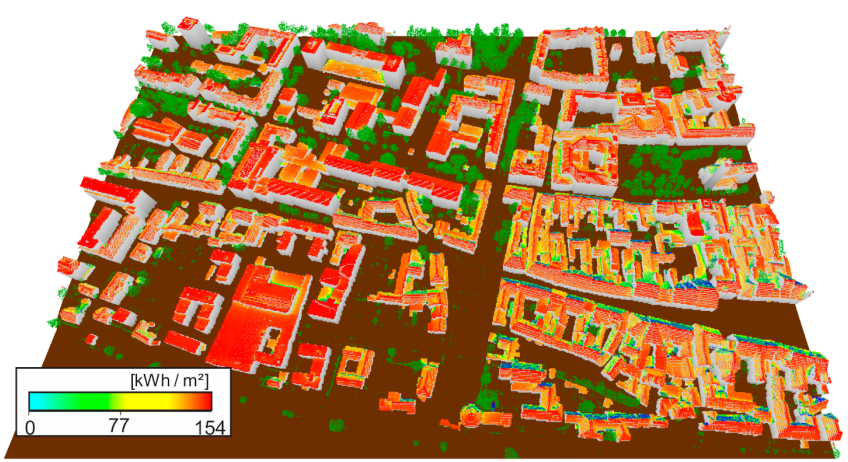

(a)

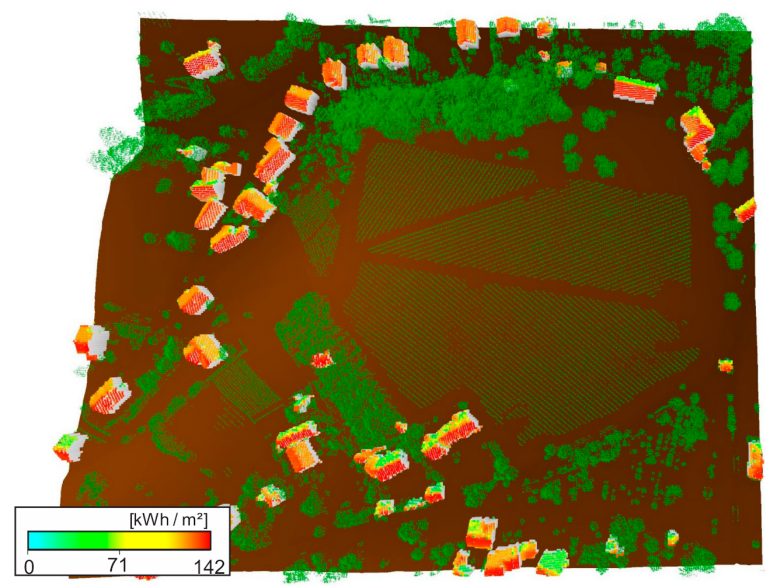

(b)

Figure 3. Estimated photovoltaic (PV) potential of the considered LiDAR scan for the (a) urban area within the city of Maribor, and (b) rural area of Pekre.

Since we know the hourly production values, we can link individual 2.5D grid cells to buildings, which in turn have a predetermined number of households. When considering self-supply, the installed power supply of an individual building consisting of one or multiple households has to be considered. 
In order to do a thorough analysis of estimated PV potential and economic return on investment, the regulatory aspects of self-supply have to be taken account, as shown in the next subsection. In this paper this is done in the case of Slovenia. A similar approach can also be used for other countries considering their regulatory framework.

\subsection{Self-Supply Regulatory Framework of Slovenia}

In the following paragraphs, the regulatory framework pertaining to the self-supply by PV systems is analysed. Relevant regulations and policy documents are summarized and discussed. The analysis is limited to those aspects of the regulatory framework which the authors believe to be relevant for this research and especially for the ensuing discussion. Selecting the Maribor city centre as the case study and applying findings to analyse the Slovenian regulatory framework is an appropriate approach, since the analysed policies are determined on the state level and are not influenced by local regulations. Findings pertaining to the Maribor city centre thus have a broader relevance for the state-level policies.

The main regulation in the Slovenian regulatory framework for the energy sector is the Energy Act (EZ-1). It is a part of primary legislation [27], which clearly states its own purpose:

'This Act lays down the principles of energy policy, energy market operation rules, the ways and forms of providing public services in the energy sector, principles and measures for achieving secure energy supply, for increasing energy efficiency and energy saving and for increasing the use of energy generated from renewable energy sources, lays down the conditions for the operation of energy installations, and regulates the responsibilities, organisation and tasks of the Energy Agency (hereinafter: the Agency) and the competences of other authorities operating under this Act [28].'

Based on the above act, self-supply was first regulated in Slovenia in 2015 with the enactment of the Decree on the self-supply of electricity from renewable energy sources [29]. The reason for the enactment of this part of secondary legislation was that it aimed at encouraging the use of electrical energy, produced from renewable energy sources. Selfsupply was understood to be the production of electrical energy from renewable sources of energy, such as sun, wind, water and geothermal energy, for a whole or partial covering of own consumption of electrical energy with a self-supply device. A self-supply device was in turn understood to be a device which produces electrical energy using solar, wind or water energy or a device for cogeneration of heat and electrical energy, which uses renewable energy sources as its primary source and is connected to the internal low-voltage electrical installation of a building. The delivery of power from the production device to the electricity distribution network was limited. The highest apparent power that was allowed to be delivered to the distribution network through a single metering point was $11 \mathrm{kVA}$ [29], whilst the self-supply and the consumption were balanced within the time interval of one year.

A new Decree on the self-supply of electricity from renewable energy sources came into force in May 2019 [30]. It introduced major changes in policy. The most important is alleviating the problems stemming from an important regulatory omission made by the previously relevant decree. Previously there was namely no legal basis which would allow households and small businesses who own premises in multi-dwelling buildings to install PV modules on rooftops of such buildings in the context of self-supply. Obviously, this had negative effects on the proliferation of PV systems, especially in urban areas, where the concentration of multi-dwelling buildings is usually relatively high. A further important regulatory change, which is more directly relevant to the present piece of research, deals with limitations on electricity delivery in the context of self-supply. While in the previous decree, limitation was set in terms of the highest allowed apparent power of the self-supply device, the new regulation sets the limitation in terms of the highest allowed connected load. For individual self-supply, the limitation is thus set by the new self-supply decree at 0.8 of the rated power at the power meter equipped point of common coupling (metering point), where the PV system is connected on the customer's internal wiring behind the 
metering point. The policy approach for multi-dwelling buildings and communities with renewable energy sources is similar. Regarding such community self-supply, the total connected power of the installed PV systems may not exceed 0.8 of the sum of rated powers at all metering points (power meter equipped points of common coupling), which are involved in such a community self-supply scheme [30]. The amendment retains other relevant definitions from the previous decree. The policy aim of the self-supply of electrical energy remains essentially the same, although a slight change of wording has been enacted, primarily to include community self-supply. Self-supply also remains relevant only for households and small-businesses who decide to install self-supply electricity production devices. In connection with this, a side-note is necessary. The definition of small businesses as relevant for the energy policy is especially problematic in the Slovenian regulatory framework and important practical ramifications for who qualifies for self-supply arise from it [31].

As the Ministry of infrastructure noted in its proposal, the new Decree on the selfsupply of electricity from renewable energy sources brings the self-supply PV systems under the Px.3 scheme [32]. This means that in terms of connecting such devices to the electricity network, general regulations from the Rules on the system operation of electricity distribution network (SONDO) apply. SONDO demands that consent for connection of a PV system must be obtained from the distribution system operator (DSO) [33]. Regarding the present piece of research, regulations regarding the limitation of energy delivered to the network from production devices are furthermore relevant. The Decree on general conditions for the supply and consumption of electricity states that the transmission of energy to the network from a production device may be limited through disconnection or through other appropriate means [34]. SONDO offer the main guidance in this regard. They state that a device for limiting the energy flow (power) can be implemented either as a main fuse or as an adjustable current limiter. For the latter, a circuit breaker is used in combination with a system counter that performs measurements. In the case of exceeded power, the possibility of a restart has to be enabled to the user by the system operator [33].

If overload of the electricity distribution network occurs, or voltage profile cannot be provided inside prescribed limits, the system operator may perform switching manipulations or other measures, which ensure that electricity production devices operate within allowed limitations. If operation within allowed limits cannot be ensured through the above means, the network is relieved through following means, in the following order:

- Relieving the network with contractually agreed users;

- Relieving the network according to the instructions for monitoring and taking action in the event of disruptions or disintegration of the electric power system;

- Disabling certain parts of the distribution network for the time that is strictly necessary to eliminate the danger [34].

Furthermore, action in case of unforeseen events is regulated by SONDO. It is stated that in case of disruptions, breakdown of the network or failure of a part of network, the system operator must perform all necessary switch manipulations to ensure the operation of the distribution network. In the above provision, it is furthermore specifically stated that this overrides any special or individual interest of the users [34]. As is typical of the energy sector in general, the production of electricity from PV systems in the context of self-supply in Slovenia is highly regulated [35]. This ensures that proliferation of PV systems for households and small businesses does not compromise network stability and with it the reliability of electricity supply through the distribution network.

What follows in the next section are the results of the analysis, which takes into account the Slovenian regulatory environment. A comparison is thus made between the current policy approach and a proposed alternative one, where limitation of power occurs only at peaks. 


\subsection{Proposed Improvement}

The self-supply analysis is performed by comparing the total instantaneous output power of two PV systems. The first PV system has the installed power equal to the rated power at the metering point (point of common coupling) of the household multiplied by 0.8 (i.e., the existing PV-based self-supply scheme in Slovenia). The second PV system has the installed power equal to the rated power at the metering point (point of common coupling) of the household, whilst its maximal peak production is limited to 0.8 of the installed PV system power, which is marked as the proposed solution. An example is shown in Figure 4 for a household with the rated power at the metering point of $10 \mathrm{~kW}$, where active power generation of the two discussed PV systems is illustrated throughout the summer solstice day.

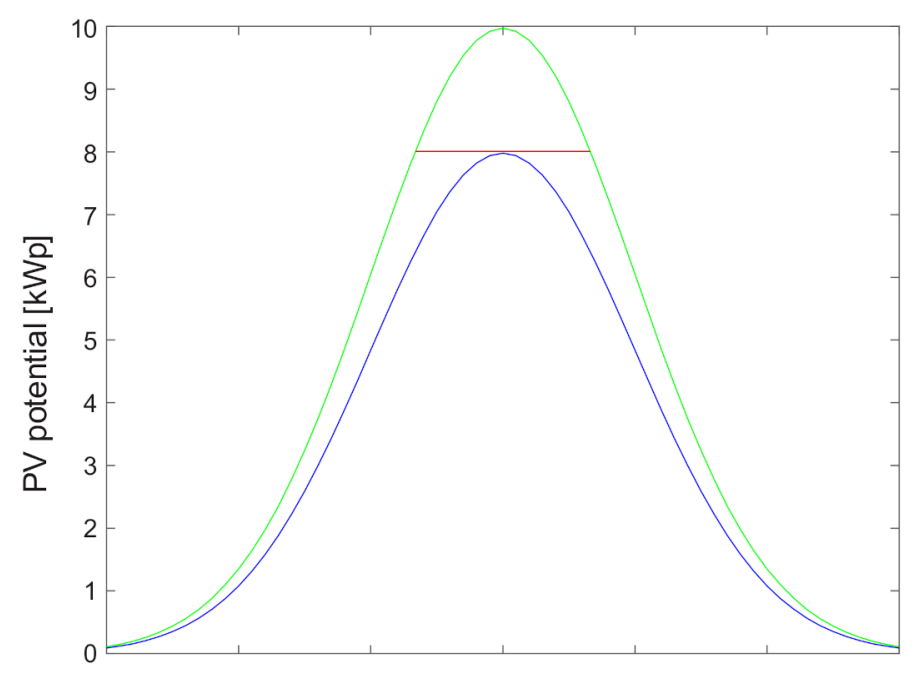

Figure 4. Example of PV potential of the two discussed PV systems. The blue line represents the PV system with the installed power $8 \mathrm{kWp}$ equal to the rated power of $10 \mathrm{~kW}$ multiplied by 0.8 .

The green line represents the PV system with the installed power of $10 \mathrm{kWp}$. The red line represents the output power limitation at $8 \mathrm{~kW}$. The current self-supply scheme in Slovenia for PV systems states that the installed PV system power, as well as the peak generation is limited to the rated power at the metering point of the household multiplied by factor 0.8 . In the continuation this is denoted as the "old scheme". If there are multiple households involved, then the total installed PV system power is limited by the sum of rated powers at the metering points of all involved households within the building. In order to test the method, the number of 2.5D grid cells (representing PV systems) was limited based on the maximum installed power of the PV system by the "old scheme" and the "proposed new" scheme (i.e., the installed PV system power equals to the rated power at the metering point, but its production is limited to 0.8 of installed power). The cumulative results for the entire year, when considering all buildings, can be seen in Figure 5, where the proposed approach outperforms the current scheme by $10 \%$ after 1 year of operation. Due to General Data Protection Regulation (GDPR) [36] and other privacy-related laws, the installed power of PV system for each individual household is not known, hence we considered the average install power of PV system in Slovenia, which at the time of this writing was $7.5 \mathrm{kWp}$. 


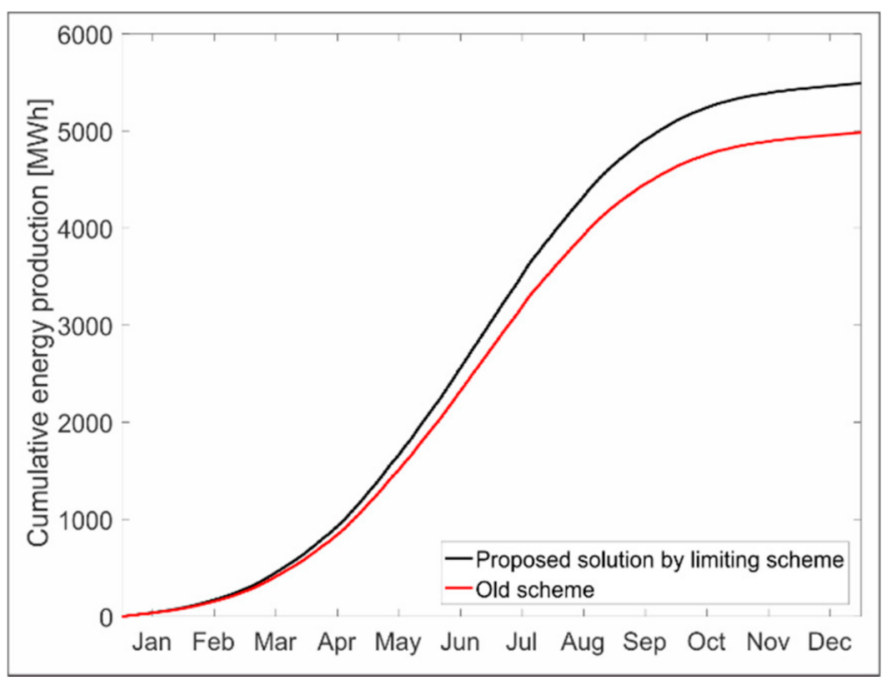

Figure 5. The cumulative energy production in urban area of Maribor estimated considering the limitations for the installed PV system power according to the proposed and the current scheme for self-supply.

Of course, the proposed scheme leads to higher installed power of PV systems which means also higher production with limited peak production values. Therefore, it is vital to perform also an economical assessment, if the proposed solution is not only technically but also economically viable. The NVP metric was estimated for both schemes for the duration of next 20 years, and the cumulative results can be seen in Figure 6. The interest rate was considered at $2 \%$, while the feed-in tariff and PV system per-watt price (including PV modules and micro inverter costs) were set to $0.27478 € / \mathrm{kWh}$ and $0.927 € / \mathrm{Wp}$, respectively, based on the data collected in [8]. The PV system's yearly degradation factor was set to $1 \%$. The proposed scheme provides an increase in income of 2 million $€$ after 20 years of operation in comparison to the old scheme.

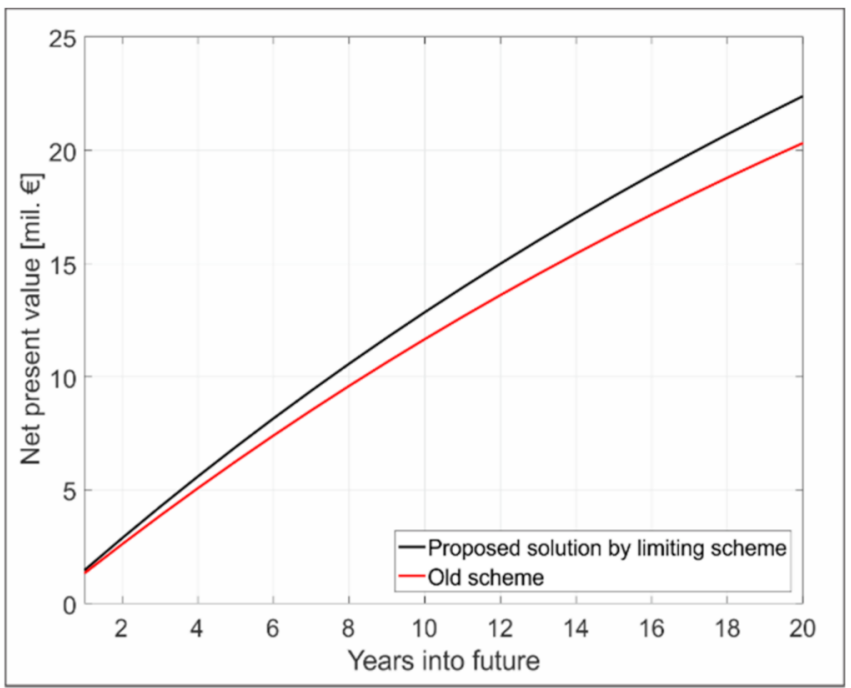

Figure 6. Comparison of NPV-based economic assessment between the proposed scheme and the old scheme for self-supply based on PV systems, given for the urban area in Maribor.

The results have shown that the proposed PV system based self-supply scheme is highly valuable to be considered in Slovenia, as it would provide higher energy production, and is in turn also more economically suitable. The proposed limiting of the PV system instantaneous output power can also be implemented in practice in straightforward manner 
with minimal cost overhead. In the next section we discuss the required policy and regulatory changes for enabling the proposed scheme in Slovenia to take effect.

\subsection{Discussion and Policy Proposal}

The primary regulatory limitation for the approach advocated for in this paper, on the basis of the performed techno-economic photovoltaic potential assessment, are the provisions of the Decree on the self-supply of electricity from renewable energy sources [30]. Articles 4 and 7 of the above decree, which deal with individual self-supply and community self-supply respectively, should be amended. The amendment should be such that regarding connecting new devices to the electricity grid, the limit of installed power of PV system set at 0.8 of the sum of rated powers at all metering points involved in the self-supply, is abolished. Self-supply devices with the installed power equal to the rated power at the metering point should be allowed to be connected to the grid.

An important further question is raised by the proposed approach, namely which entity should ensure the limitation of PV system output power during peak production hours. It seems that in the Slovenian regulatory framework, the distribution system operator (DSO) is the most appropriate stakeholder to ensure the output power limitation to 0.8 of the installed PV system power during the peak production hours, if this is required form the network operation point of view. An alternative solution, where an entity other than the DSO would ensure the above limitation during peak production hours, is not possible anyway in accordance with current legislation both at the national and the EU level. At the EU level, unbundling is required and that means, among others, that network services dealing with distribution should be separated from both production and supply [37]. At the Slovenian national level, distribution network-related services are entrusted to the DSO [38]. Since policy solutions potentially entrusting the limitation of self-supply PV systems output power during the peak production hours to entities other than the DSO would require significant changes both at the EU and national legislative levels, they are to be deemed highly impractical from the policy perspective and the solution involving the DSO is to be endorsed. In order for the DSO to have a sufficient basis and right to perform the necessary manipulations to ensure limitation of self-supply PV systems output power to 0.8 of the installed power during the peak production hours, a slight amendment of the existing regulatory framework is necessary. In the Rules on the system operation of electricity distribution network (SONDO), which is a piece of secondary legislation, we propose an additional Article:

'DSO may perform necessary manipulations to ensure limitation of self-supply

$\mathrm{PV}$ devices to 0.8 of the installed power during the peak production hours, if this is required to assure proper operation of distribution network.'

The proposed regulatory change retains connecting of self-supply PV devices to the distribution network in the context of the Px.3 scheme, while at the same time circumvents the need for change in primary legislation and allows for proposed limitation during peak production hours. This is desirable from the standpoint of actual possibility to achieve such a policy change. Since only secondary legislation, namely the SONDO and the Decree on the self-supply of electricity from renewable energy sources need to be amended, a parliamentary procedure with lengthy and often chaotic [39] deliberations is not necessary. In accordance with the existing regulatory framework, SONDO may be amended by the DSO, with consent of the Slovenian Energy Agency and with additional consent from the government of the Republic of Slovenia [28]. The government may also amend the Decree on the self-supply of electricity from renewable energy sources, without any need for a parliamentary procedure [28].

All of the above thus clearly shows that the proposed alternative approach, with the limitation of production during peak production hours, is not only superior to the current approach to production of electricity with PV systems in the context of self-supply framework, but also one that can be relatively easily implemented in terms of policy change. 
Moreover, the proposed techno-economic potential estimation is also applicable for other countries, if local regulatory framework is considered.

\section{Conclusions}

In proliferation of PV systems, especially with policies for achieving optimum production is an important challenge. In this regard, technological solutions need to go hand in hand with efficient regulatory approaches. In this paper, state-of-the-art photovoltaic potential estimation using LiDAR data was used in combination with publicly available data pertaining to the PV potential.

The proposed approach for techno-economic potential estimation is generally applicable. In the case study, given for the city centre of Maribor and rural area of Pekre, Slovenia, it was applied for the Slovenian self-supply scheme. The result of the performed analysis is the proposition of the necessary legislative amendments to the current regulatory framework were presented. Limitation of the installed power of the PV system to 0.8 of the rated power at the metering point (point of common coupling), which is the current policy approach, was found to not be optimal. Relevant Slovenian self-supply regulations should be amended to allow higher installed power of PV systems with possible (and flexible) limitation of output power during hours with peak production, in order to achieve higher energy production from PV systems. Changes of relevant regulations could be enacted by the Slovenian legislative authorities, as proposed by this paper, in order to optimize production in the context of the Slovenian self-supply PV scheme.

This was thus the first study have considered PV potential over LiDAR data for the validation of different self-sustainability scenarios based on Slovenia's regulatory selfsupply policies and where such state-of-the-art techno-economic scientific analysis was used to explore advantages and disadvantages of different self-supply policy approaches. Furthermore, it was the first scientific analysis of legal and regulatory aspects pertaining to self-supply in the Slovenian regulatory framework.

The approach used in this research regarding techno-economic photovoltaic potential assessment is generally applicable and can also be replicated in order to ascertain the merits or demerits of different policy approaches in regulatory environments of other countries. The combination of state-of-the-art methodology to measure PV potential and an in depth understanding of the regulatory environment of an analysed country opens doors to potential further research in similar veins. Of course, in performing similar research, local regulatory frameworks both on the level of primary and secondary legislation have to be taken into account and the techno-economic assessment has to be tailored in order to retain relevance on the basis of particular national or local regulations and policies. In the global context, such an approach could thus enable a bottom-up achievement of a higher degree of efficient sustainability-related policy solutions, which stems from improvements of regulations in individual jurisdictions.

Author Contributions: L.M.T. for the regulatory aspects and original draft preparation. N.L. for the techno-economic potential assessment, review and editing. G.Š. for the grid related issues and supervision. All authors have read and agreed to the published version of the manuscript.

Funding: The authors acknowledge the financial support from the Slovenian Research Agency (Research Core Funding No. P2-0041 and P2-0115, as well as Research Projects No. L2-1826 and J2-1742).

Data Availability Statement: Data available in a publicly accessible repository that does not issue DOIs; Publicly available LiDAR datasets from Slovenian Environmental Agency were analyzed in this study. This data can be found here: http://gis.arso.gov.si/evode/profile.aspx?id=atlas_voda_ Lidar@Arso\&culture=en-US.

Conflicts of Interest: The authors declare no conflict of interest. 


$\begin{array}{lll}\text { Abbreviations } & \\ \text { Symbol } & \text { Unit } & \text { Description } \\ G & / & \text { 2.5 grid } \\ p & / & \text { 3D point } \\ c & / & \text { 2.5 grid cell } \\ \beta & / & \text { Slope angle } \\ \gamma & / & \text { Aspect angle } \\ P & \mathrm{kWh} & \text { PV potential } \\ P S Y S & \text { W } & \text { PV system output power } \\ S & / & \text { Shadowing coefficient } \\ \theta & / & \text { Angle of incidence } \\ \theta_{z} & / & \text { Zenith angle } \\ I_{d} & \text { W } / \mathrm{m}^{2} & \text { Diffuse irradiance } \\ I_{b} & \text { W } / \mathrm{m}^{2} & \text { Direct irradiance } \\ \eta^{X} & / & \text { Non-linear efficiency characteristics function for PV module X. } \\ \eta^{i n v} & / & \text { Non-linear efficiency characteristics function for PV inverter. } \\ x & / & \text { Regression coefficients for } \eta^{X} \\ A & \mathrm{~m}^{2} & \text { PV module area } \\ \Omega & / & \text { Hour angle } \\ \delta & / & \text { Solar declination angle } \\ \mathrm{H} & / & \text { Hour } \\ \mathrm{n} & / & \text { Day } \\ \mathrm{B} & / & \text { Normalization coefficient used in } \delta \\ \varphi & / & \text { Geographical latitude } \\ \mathbf{s} & / & \text { Sun's light directional vector } \\ N P V & € & \text { Net present value } \\ F & € & \text { Feed-in-tarrif } \\ I N V & € & \text { Initial investment } \\ r & \% & \text { Discount rate } \\ a & \% & \text { PV degradation coefficient } \\ & & \end{array}$

\section{References}

1. Hancher, L.; Winters, B.M. Briefing Paper: The EU Winter Package. Available online: https://fsr.eui.eu/wp-content/uploads/ The-EU-Winter-Package.pdf (accessed on 18 June 2019).

2. European Commission. Winter Package 2016. Available online: https://ec.europa.eu/energy/en/content/energy-efficiencydirective-winter-package-2016 (accessed on 25 December 2019).

3. European Commission. Clean Energy for All Europeans. Available online: https://op.europa.eu/en/publication-detail/-/ publication/b4e46873-7528-11e9-9f05-01aa75ed71a1/language-en?WT.mc_id=Searchresult\&WT.ria_c=null\&WT.ria_f=3608 \&WT.ria_ev=search (accessed on 20 November 2019).

4. Government of the Republic of Slovenia. Proposal for the Act of Changes and Amendments of the Energy Act; Proposal EVA 20182430-0100; 21 January 2019. Available online: https://e-uprava.gov.si/.download/edemokracija/datotekaVsebina/375829 ?disposition=inline (accessed on 23 January 2021).

5. Biljecki, F.; Heuvelink, G.; Ledoux, H.; Stoter, J. The effect of acquisition error and level of detail on the accuracy of spatial analyses. Cartogr. Geogr. Inf. Sci. 2018, 45, 156-176. [CrossRef]

6. Tooke, T.R.; Coops, N.C.; Christen, A.; Gurtuna, O.; Prévot, A. Integrated irradiance modelling in the urban environment based on remotely sensed data. Sol. Energy 2012, 86, 2923-2934. [CrossRef]

7. Brito, M.; Gomes, N.; Santos, T.; Tened'orio, J. Photovoltaic potential in a Lisbon suburb using LiDAR data. Sol. Energy 2012, 86, 283-288. [CrossRef]

8. Lukač, N.; Špelič, D.; Štumberger, G.; Žalik, B. Optimisation for large-scale photovoltaic arrays' placement based on Light Detection and Ranging data. Appl. Energy 2020, 263, 114592. [CrossRef]

9. Jakubiec, J.A.; Reinhart, C.F. A method for predicting city-wide electricity gains from photovoltaic panels based on LiDAR and GIS data combined with hourly Daysim simulations. Sol. Energy 2013, 93, 127-143. [CrossRef]

10. Lingfors, D.; Killinger, S.; Engerer, N.A.; Widena, J.; Bright, J.M. Identification of PV system shading using a LiDAR-based solar resource assessment model: An evaluation and cross-validation. Sol. Energy 2018, 159, 157-172. [CrossRef]

11. Assouline, D.; Mohajeri, N.; Scartezzini, J.-L. Quantifying rooftop photovoltaic solar energy potential: A machine learning approach. Sol. Energy 2017, 141, 278-296. [CrossRef] 
12. Assouline, D.; Mohajeri, N.; Scartezzini, J.-L. Large-scale rooftop solar photovoltaic technical potential estimation using Random Forests. Appl. Energy 2018, 217, 189-211. [CrossRef]

13. Bizjak, M.; Žalik, B.; Štumberger, G.; Lukač, N. Large-scale estimation of buildings' thermal load using LiDAR data. Energy Build. 2020, 231, 110626. [CrossRef]

14. Oozeki, T.; Yamada, T.; Otani, K.; Takashima, T.; Kato, K. Performance trends in grid-connected photovoltaic systems for public and industrial use in Japan. Prog. Photovolt. Res. Appl. 2010, 8, 596-602. [CrossRef]

15. Nikolovski, S.; Baghaee, H.R.; Mlakić, D. ANFIS-based Peak Power Shaving/Curtailment in Microgrids Including PV Units and BESS-s. Energies 2018, 11, 2953. [CrossRef]

16. Prenc, R.; Škrlec, D.; Komen, V. Optimal PV system placement in a distribution network on the basis of daily power consumption and production fluctuation. In Proceedings of the Eurocon, Zagreb, Croatia, 1-4 July 2013; pp. 777-783.

17. Prata, R.; Carvallho, P.M.S. Self-supply and regulated tariffs: Dynamic equilibria between photovoltaic market evolution and rate structures to ensure network sustainability. Util. Policy 2018, 50, 111-123. [CrossRef]

18. Davies, L.L.; Carley, S. Emerging shadows in national solar policy? Nevada's net metering transition in context. Electr. J. 2017, 1, 33-42. [CrossRef]

19. Mongus, D.; Lukač, N.; Žalik, B. Ground and building extraction from LiDAR data based on differential morphological profiles and locally fitted surfaces. Isprs J. Photogramm. Remote Sens. 2014, 9, 145-156. [CrossRef]

20. Hall, I.J.; Prairie, R.R.; Anderson, H.E.; Boes, E.C. Generation of a Typical Meteorological Year; Sandia Labs: Albuquerque, NM, USA, 1978.

21. Duffie, J.A.; Beckman, W.A. Solar Engineering of Thermal Processes; Wiley-Interscience: Hoboken, NJ, USA, 2006.

22. Spencer, J.W. Fourier Series Representation of the position of the Sun. Search 1971, 2, 172.

23. Perez, R.; Seals, R.; Ineichen, P.; Stewart, R.; Menicucci, D. A new simplified version of the Perez diuse irradiance model for tilted surfaces. Sol. Energy 1987, 39, 221-231. [CrossRef]

24. Reda, I.; Andreas, A. Solar position algorithm for solar radiation applications. Sol. Energy 2004, 76, 577-589.

25. Slovenian Mapping Authority. Available online: https://www.gov.si/en/state-authorities/bodies-within-ministries/surveyingand-mapping-authority/ (accessed on 25 December 2019).

26. Slovenian Meteorological Agency. Available online: http:/ / www.arso.gov.si/en/ (accessed on 25 December 2019 ).

27. Burrows, J. Legislation: Primary, Secondary and Tertiary. Univ. Wellingt. Law Rev. 2011, 42, 65-82. [CrossRef]

28. Official Gazette of the Republic of Slovenia. Energy Act-EZ-1. Uradni list RS. No 60/19, 65/20 in 158/20-ZURE; Articles 1, 144, 314 and 315. Available online: http:/ / www.pisrs.si/Pis.web/pregledPredpisa?id=ZAKO6665 (accessed on 23 January 2021).

29. Official Gazette of the Republic of Slovenia. Decree on the Self-Supply of Electricity from Renewable Energy Sources. Uradni list RS. No. 97/15, 32/18; Articles 1, 2 and 3. Available online: https://www.uradni-list.si/glasilo-uradni-list-rs/vsebina/124314\#! /Uredba-o-samooskrbi-z-elektricno-energijo-iz-obnovljivih-virov-energije (accessed on 23 January 2021).

30. Official Gazette of the Republic of Slovenia. Decree on the Self-Supply of Electricity from Renewable Energy Sources. Uradni list RS. No. 17/19, 197/20; Articles 4 and 7. Available online: http://www.pisrs.si/Pis.web/pregledPredpisa?id=URED7867 (accessed on 23 January 2021).

31. Tomažič, L.M.; Brandner, H. Issues regarding (small) business customers with several consumption points. In Prekrškovno Pravo Energetike; Bratina, B., Šepec, M., Tomažič, L.M., Stajnko, J., Eds.; Univerzitetna Založba Univerze v Mariboru: Maribor, Slovenia, 2020; pp. 277-288.

32. Ministry of Infrastructure. Proposal for the Decree on the Self-Supply of Electricity from Renewable Energy Sources; Proposal EVA 2018-2430-0110; 21 December 2018. Available online: https://e-uprava.gov.si/.download/edemokracija/datotekaVsebina/3825 18?disposition=inline (accessed on 23 January 2021).

33. Official Gazette of the Republic of Slovenia. Rules on the System Operation of Electricity Distribution Network-SONDO. Uradni list RS. No. 41/11; Articles 17, 18, 67, 68, 70 and 125. Available online: http:/ /www.pisrs.si/Pis.web/pregledPredpisa?id=NAVO1023 (accessed on 23 January 2021).

34. Official Gazette of the Republic of Slovenia. Decree on General Conditions for the Supply and Consumption of Electricity. Uradni list RS. No. 117/02, 21/03; Article 47. Available online: http:/ / www.pisrs.si/Pis.web/pregledPredpisa?id=URED2654 (accessed on 23 January 2021).

35. Hoppe, T.; Butenko, A.; Heldeweg, M. Innovation in the European Energy Sector and Regulatory Responses to It: Guest Editorial Note. Sustainability 2018, 10, 416. [CrossRef]

36. Regulation (EU) 2016/679 of the European Parliament and of the Council of 27 April 2016 on the Protection of natural persons with Regard to the Processing of Personal Data and on the Free Movement of Such Data, and Repealing Directive 95/46/EC (General Data Protection Regulation), General Data Protection Regulation (GDPR). Available online: https: / / eur-lex.europa.eu/ eli/reg/2016/679/oj (accessed on 25 December 2019).

37. Kulovesi, K.; Morgera, E.; Munoz, M. Environmental integration and multi-faceted international dimensions of EU law: Unpacking the EU's 2009 climate and energy package. Common Mark. Law Rev. 2011, 48, 829-891.

38. Official Gazette of the Republic of Slovenia. Decree on the Method of Provision of an Electricity DSO Service of General Economic Interest and a Service of General Economic Interest of Electricity Supply to Tariff. Uradni list RS. No. 117/04, 23/07. Available online: http:/ / www.pisrs.si /Pis.web/pregledPredpisa?id=URED3449 (accessed on 23 January 2021).

39. Kingdom, J.W. Agendas, Alternatives, and Public Policies; Little Brown: Boston, MA, USA, 1984. 